Original article

\title{
The outbreak of COVID-19: Resilience and its predictors among parents of schoolchildren carrying out online learning in Indonesia
}

\author{
Abd Nasir $^{\text {a,b, }}$, Susilo Harianto ${ }^{\text {a,b }}$, Cucuk Rahmadi Purwanto ${ }^{\mathrm{a}, \mathrm{b}}$, Iswatun ${ }^{\mathrm{a}, \mathrm{b}}$, Retno Indrawati ${ }^{\mathrm{a}}$, \\ Makhfudli $^{\text {a,b }}$, Rohman ${ }^{\text {a,c }}$, Ernawati ${ }^{\text {a,c }}$, Primasari M. Rahmawati ${ }^{\text {d }}$, I.Putu.G.Y.S. Putra ${ }^{\text {d }}$ \\ ${ }^{\text {a }}$ Faculty of Nursing, Airlangga University, Surabaya, Indonesia \\ ${ }^{\mathrm{b}}$ Faculty of Vocational, Airlangga University, Surabaya, Indonesia \\ ${ }^{\mathrm{c}}$ Universitas Muhammadiyah, Jakarta, Indonesia \\ ${ }^{\mathrm{d}}$ Mental Health Nursing Department, School of Nursing Jember University, Indonesia
}

\section{A R T I C L E I N F O}

\section{Keywords:}

Parents

Resilience

Covid-19 outbreak

Online learning

\begin{abstract}
A B S T R A C T
Objective: Online learning during the COVID-19 outbreak, puts mental stress on parents and their children so that this requires extraordinary resilience when parents get additional tasks to accompany children in online learning that is done at home. The current study seeks to evaluate the resilience of parents accompanying schoolchildren in online learning. Besides, this study also examines independent socio-demographic predictors of parental resilience.

Methods: This descriptive-analytic cross-sectional study was conducted on 392 parents of children participating in online learning at home. Data were collected through an online questionnaire survey in the provinces of Java and Bali. Demographic questionnaires and the Connor-Davidson Resilience Scale (CD-RISC) were used to collect data. Data were analyzed using descriptive statistics and regression analysis with $\mathrm{p}<0.05$.

Results: Simultaneously the independent variables affect the resilience of parents as indicated by the value of $\mathrm{F}$ (9.010), p-value (0.000), and $\mathrm{R}(0.376)$. The predictors of parental resilience were the gender of the parents with the t-value (3.280), p-value (0.001), $\beta$ (4.572), parent's employment status with the t-value (3.752), p-value (0.001), $\beta$ (4,348), financial status with the t-value (4.754), p-value (0.000), $\beta$ (5.087), and the gender of the children with the t-value (2.849), p-value (0.005), $\beta$ (4.873).

Conclusion: Predictor factors that affect the resilience of parents in providing online learning assistance during the COVID-19 pandemic need to get more serious attention, especially for mothers who have lower resilience than fathers. So that their children can still achieve better academic achievements
\end{abstract}

\section{Introduction}

The COVID-19 outbreak has forced learning settings to be done online to avoid cross-infection among schoolchildren ${ }^{1}$ and this is very troublesome for the parents of their school-age children. ${ }^{2}$ UNESCO noted that 188 countries have suspended schools nationally and as many as $90 \%$ of school children (1.5 billion young people) carry out the education process outside of school. ${ }^{3}$ This was also followed by the Indonesian government by issuing circular letter number 4 of 2020 concerning the Implementation of Educational Policies in the
Emergency Period for the Spread of Corona Virus Disease (COVID-19) to prohibit offline learning at all levels of education and replace it with online learning. The current study seeks to evaluate the resilience of mothers accompanying schoolchildren in online learning. Additionally, this study examined the independent socio-demographic predictors of parental resilience. Meanwhile, concerning the impact caused by online learning, mainly mothers experience a very strong stress level of $71.88 \%{ }^{4}$

Parents' primary reactions to online learning for their children are often associated with trauma and shock, ${ }^{2}$ and all related to very stressful

\footnotetext{
* Corresponding author. Faculty of Vocational, Universitas Airlangga, Airlangga University Campus B, Jl. Dharmawangsa Dalam Selatan No.28 - 30, Airlangga Gubeng, Surabaya city, East Java, 60286, Indonesia.

E-mail addresses: abdoel.nasir@vokasi.unair.ac.id, abdoel.nasir@gmail.com (A. Nasir), Susilo.harianto@vokasi.unair.ac.id (S. Harianto), pcucukrahmadi@vokasi. unair.ac.id (C.R. Purwanto), iswatun@vokasi.unair.ac.id (Iswatun), retno-i@fkp.unair.ac.id (R. Indrawati), makhfudli@fkp.unair.ac.id (Makhfudli), rohmanazzam@ umj.ac.id (Rohman), ernawati@unimus.ac.id (Ernawati), ns.primahardhika@unej.ac.id (P.M. Rahmawati), putuyudara@itekes-bali.ac.id (I.Putu.G.Y.S. Putra).
} 
stress can cause physical, psychological, and social problems that affect their adaptation. ${ }^{5}$ Psychological and clinical assessments show increased levels of depression and anxiety among parents of children doing online learning during this COVID-19 outbreak, and some parents experience different psychosocial problems, ranging from financial pressure, difficulty in understanding children's lessons and changing children's roles, and work and family conflicts to lack of time for other children. ${ }^{4}$ Besides, psycho-emotional dysfunction among parents can have an impact on psychological well-being and family well-being. ${ }^{6}$

Parental resilience is the key to all effective coping strategies related to various online learning problems from school-age children. This indicates that parents need resilience and adaptive skills to overcome online learning difficulties for their children. Meanwhile, for the fulfillment of personal needs, the benefits of resilience for online learning problems in school-age children are able to overcome the inconvenience of parents. Resilience is also a significant predictor of effective coping in children with high levels of assistance such as persons with disabilities. ${ }^{7}$ Furthermore, toughness is needed for parents of children who do online learning to improve their psychological well-being and life satisfaction and reduce their burden. On the other hand, a lack of resilience can increase the risk of various mental and physical endurance problems. Therefore, resistance is considered a protective factor against various health problems and risks. ${ }^{8}$

Giving the understanding of the importance of resilience in supporting psychological well-being for individuals and families and determining contributing factors can increase the resilience of individuals and families to health problems. ${ }^{9}$ However, most studies on resilience in some countries related to parents of school-age children are limited to parents with chronically ill children, ${ }^{10}$ and thus there is limited information on resilience among parents of school-age children undertaking online learning. To bridge this gap, this study was conducted to assess resilience and its predictors in mothers with school-age children doing online learning.

\section{Methods}

\subsection{Study design}

The cross-sectional with descriptive-analytical was used in this study. The population consisted of all parents of students who participated in online learning chosen using consecutive sampling in which the data was collected through an online questionnaire survey on the islands of Java and Bali, Indonesia. The Cochran's sample size formula indicated that at least 385 parents were needed. The sample size was increased to 392 due to possible dropouts. The inclusion criteria for parents were having children who did online learning and were able to use internet applications. For the first time, the respondent was asked the question "are you a parent who has an additional task of assisting children in online learning". If you answer "Yes", and "if you are willing to participate in this study, you can click the approval button". For sampling, the researchers used a mobile phone that was already in the application to answer the research instrument. Sampling and data collection were carried out in April-May 2021.

\subsection{Instrument}

Data collection used The Connor-Davidson Resilience Scale (CDRISC) consisted of 25 items that have been tested for validity and reliability with Cronbach's alpha of 0.89 and test-retest correlation coefficient of $0.87 .{ }^{11}$ The results of the validity and reliability test for this resilience scale of Cronbach's alpha was 0.95 . The demographic questionnaire included items on the gender of parents, place of residence, father's occupation, maternal occupation, parental education, and parents' socioeconomic conditions. Meanwhile, the demographic data of children included the gender of the child, the number of children in the family, and the ability to use the mobile application.

\subsection{Data analysis}

Data analysis used the SPSS Program for Windows version 22 (SPSS Inc., Chicago, IL, USA). General data has been presented through descriptive statistics such as absolute and relative frequency, mean, and standard deviation using regression analysis of $\mathrm{p}<0.05$.

\subsection{Ethical considerations}

Ethical approval for this study was obtained from the ethics committee at STIKES Muhammadiyah Lamongan with registration No. 084/ EC/KEPK - S2/04/2021. Parents signed the consent form. Besides, children were also asked whether they agreed before being included in the study. Participants were assured of the confidentiality and anonymity of their participation. $\left(29^{\text {th }}\right.$ of April 2021)

\section{Results}

In total, 392 parents of children doing online learning were studied. The participants were 106 mothers and 286 fathers. The age of the parents ranged from 22 to 42 years. Besides, $47.4 \%$ of fathers and $9.8 \%$ of mothers worked. Approximately $14.28 \%$ of children were the only children in their families. Mathematics was a subject that children find difficult when learning online (47.96\%). Table 1 summarizes the demographic characteristics of parents and children.

Through regression analysis, the results of the analysis of coefficients

Table 1

The relationship of resilience with parent's and children's demographic characteristics.

\begin{tabular}{|c|c|c|c|}
\hline \multirow[t]{2}{*}{ Characteristics } & \multirow[t]{2}{*}{ n (\%) } & \multicolumn{2}{|c|}{ Resilience } \\
\hline & & Means & SD \\
\hline \multicolumn{4}{|l|}{ Parents } \\
\hline \multicolumn{4}{|l|}{ Parent's gender } \\
\hline Father & $103(26,35)$ & 81.895 & 12.019 \\
\hline Mother & $288(73,65)$ & 79.544 & 9.123 \\
\hline \multicolumn{4}{|l|}{ Place of residence } \\
\hline Rural areas & $224(57,30)$ & 81.043 & 9,605 \\
\hline Urban areas & $167(42,70)$ & 79.022 & 10.439 \\
\hline \multicolumn{4}{|c|}{ Mother's employment status } \\
\hline Housewives & $121(42,01)$ & 78.023 & 9.734 \\
\hline Employed & $167(57,99)$ & 80.646 & 8.515 \\
\hline \multicolumn{4}{|c|}{ Father's employment status } \\
\hline White-collar worker & $31(30,10)$ & 75.071 & 12.980 \\
\hline Farmer & $16(15,50)$ & 81.400 & 8.996 \\
\hline Self-employed & $56(54,40)$ & 85.814 & 10.583 \\
\hline \multicolumn{4}{|l|}{ Financial status } \\
\hline Good & $79(20,20)$ & 75.117 & 11.405 \\
\hline Moderate & $215(55,00)$ & 81.067 & 8.399 \\
\hline Poor & $97(24,80)$ & 83.898 & 9.945 \\
\hline \multicolumn{4}{|l|}{ Internet affordability } \\
\hline Good & $129(26,10)$ & 75.793 & 12.009 \\
\hline Moderate & $204(52,20)$ & 80.152 & 9.578 \\
\hline Poor & $58(14,8)$ & 82.145 & 9.093 \\
\hline \multicolumn{4}{|c|}{ Ability to use the internet network } \\
\hline Good & $102(26,10)$ & 79.654 & 10.532 \\
\hline Moderate & $289(73,90)$ & 81.607 & 8.839 \\
\hline \multicolumn{4}{|l|}{ Children } \\
\hline \multicolumn{4}{|l|}{ Children's gender } \\
\hline Male & $181(46,30)$ & 81.272 & 8.901 \\
\hline Female & $210(53,70)$ & 79.207 & 10.798 \\
\hline \multicolumn{4}{|l|}{ Number of children } \\
\hline 1 & $56(14,29)$ & 75.785 & 10.389 \\
\hline$>1$ & $336(85,71)$ & 80.895 & 9.766 \\
\hline \multicolumn{4}{|c|}{ Types of lessons that children find difficult when learning online } \\
\hline Mathematics & $152(38,90)$ & 80.315 & 9.831 \\
\hline English & $142(38,90)$ & 80.625 & 9.807 \\
\hline Natural Sciences & $76(19,40)$ & 78.442 & 10.757 \\
\hline Indonesian & $10(2,60)$ & 83.440 & 7.322 \\
\hline Social Sciences & $9(2,30)$ & 82.755 & 11.893 \\
\hline Religion & $2(5,00)$ & 73.200 & 8.646 \\
\hline
\end{tabular}


with a value of constant (25.165) showed that the $t$-test obtained a value for parent's gender with the t-value (3.280), p-value (0.001), parent's employment status with the t-value (3.752), p-value (0.001), place of residence with the t-value (-.132), p-value (0.895), economic status with the $t$ value (4.754), $p$-value $(0.000)$, internet affordability with the $t$ value (1.516), $p$-value (0.130), ability to use the internet with the $t$ value $(-1.699)$, p-value (0.090), number of children in the family with the $t$ value (1.801), $p$-value (2.189), and gender of the children with the $t$ value (2.849), p-value (0.005). While, based on the results of the regression coefficient test, the beta $(\beta)$ value of each item were parent's gender (4.572), parent's employment status $(4,348)$, place of residence (-.177), economic status (5.087), internet affordability (1.783), ability to use the internet $(-2.799)$, number of children in the family $(2,189)$, and gender of the children $(4,873)$. Further details can be seen in Table 2.

Meanwhile, to determine the relationship between the independent and dependent variables, a regression test has been carried out using 1-5 model tests. And simultaneously, parents' gender, parents' employment status, place of residence, economic status, internet affordability, ability to use the internet, number of children in the family, and gender of children affect the resilience of parents, which is indicated by the evaluation of model 1 with the value of $F$ (9.010), p.value (0.000) and R (0.376), and the detail can be seen in Table 3. Then, the variables that have a significant relationship to the resilience of parents in accompanying children to participate in online learning are the gender of the parents, the employment status of the parents, the economic status, and the gender of the children, as evidenced by the highest significance value.

\section{Discussion}

\subsection{Parental resilience}

The total parental resilience score was $80,163 \pm 10.006$, in which the mean score of fathers resilience was $81,895 \pm 12,019$, and maternal resilience was $79,544 \pm 9,123$. These findings indicated that children with online learning had a high level of dependence on parents, and this is often experienced in childhood because they are helpless against the difficulties experienced. Besides, school-age children often have difficulty in understanding and detecting hierarchical structures, grammar, and writing. ${ }^{12}$ This is in line with other studies that indicate a high level of dependency such as cancer children due to helplessness, so they are very dependent on their parents with the parental resilience of $67.59 \pm$ $13.74^{13}$ These findings indicated that parents of school-age children in online learning settings had low to moderate resilience. However, their resilience is still better than people who work in a stressful environment such as mental illness caregivers. ${ }^{14}$ These findings suggested that experiencing manageable problems associated with online learning in

Table 2

Results Analysis coefficients.

\begin{tabular}{lllll}
\hline Models & Independent Variable & \multicolumn{2}{l}{ T-test } & \multirow{2}{*}{$\begin{array}{l}\text { Regression Coefficient } \\
\text { (Beta }(\beta))\end{array}$} \\
\cline { 3 - 4 } & & $\mathrm{T}$ & $\mathrm{Sig}$ & \\
\hline \multirow{2}{*}{1} & (Constant) & 25.165 & 0.000 & 86.412 \\
& Parent's Gender & 3.280 & 0.001 & 4.572 \\
& Parent's employment & 3.752 & 0.001 & 4,348 \\
& status & & & \\
& Place of Residence & -.132 & 0.895 & -.177 \\
& Economic Status & 4.754 & 0.000 & 5.087 \\
& Internet Affordability & 1.516 & 0.130 & 1.783 \\
& Ability to Use The & -1.699 & 0.090 & -2.799 \\
& Internet & & & \\
& Number of Children in & 1.801 & 0.073 & 2.189 \\
& Family & & & \\
& Gender of Children & 2.849 & 0.005 & 4.873 \\
\hline
\end{tabular}

Dependent Variable: Resilience.
Table 3

Analisys regresion.

\begin{tabular}{llllll}
\hline \multirow{2}{*}{ Models } & \multicolumn{2}{l}{ Anova } & & \multicolumn{2}{l}{ Autocorrelation Test } \\
\cline { 2 - 3 } \cline { 5 - 6 } & F & Sig & & R & R Square \\
\hline 1 & 9.010 & $0.000^{\mathrm{a}}$ & & $.376^{\mathrm{a}}$ & .141 \\
2 & 10.536 & $0.000^{\mathrm{b}}$ & & $.376^{\mathrm{b}}$ & .141 \\
3 & 12.136 & $0.000^{\mathrm{c}}$ & & $.369^{\mathrm{c}}$ & .136 \\
4 & 14.792 & $0.000^{\mathrm{d}}$ & & $.365^{\mathrm{d}}$ & .133 \\
5 & 18.496 & $0.000^{\mathrm{e}}$ & & $.354^{\mathrm{e}}$ & .125 \\
\hline
\end{tabular}

1. Predictors: (Constant), gender of children, place of residence, gender of parents, parent's employment status, number of children in the family, ability to use the internet, economic status, and internet affordability.

2. Predictors: (Constant), gender of children, gender of parents, parent's employment status, number of children in the family, ability to use the internet, economic status, and internet affordability.

3. Predictors: (Constant), gender of children, gender of parents, parent's employment status, number of children in the family, ability to use the internet, and economic status.

4. Predictors: (Constant), gender of children, gender of parents, parent's employment status, number of children in the family, and economic status.

5. Predictors: (Constant), child's gender, parent's gender, parent's employment status, and economic status.

6. Dependent Variable: Resilience.

school-age children increased the resilience of parents in the future so that nurses' involvement becomes very important through community mental health nursing practice in strengthening their resilience.

These findings also indicated that the mean score of resilience in fathers was significantly greater than that of mothers. This study is in line with other studies related to the resilience of parents to high stressors such as the case of intellectual disability which reported that the fathers of their children were significantly more resilient than their mothers. ${ }^{15}$ Another study related to psychological stress reported that mothers of school-age children who do online learning experience more psychological stress than fathers, and that women are indeed more sensitive than men in responding to any traumatic event, and easy to experience crises situations and prolonged sadness. ${ }^{16}$ However, in some countries, sensitivity to stress responses that affect their resilience, does not depend on gender differences, but is related to their socio-cultural. ${ }^{17}$

\subsection{Predictors of resilience in parents}

The predictor factors that significantly affect the resilience of parents are financial status, gender of parents, father's employment status, and gender of children. Likewise, other studies have reported that resilience is significantly correlated with gender and parental income. ${ }^{18}$ Good financial status is expected to reduce mental stress among parents of children who do online learning because finance usually greatly affects psychological status. ${ }^{19}$ This is in line with the findings in this study which indicated that there were financial problems between parents and school-age children who did online learning. However, not all bad socioeconomic always affect a person's resilience, because she or he can still adapt to dangerous risks and threats through positive self-development, however, women still need social support from family and friends ${ }^{20}$

The results of this study also reported that the father's job status had a positive contribution to parental resilience so that fathers with established jobs had stronger resilience than others. This is in line with the findings of other studies which reported that work factors correlated with educational factors, and this was related to the family social status which was identified as a predictor of parental resilience. ${ }^{21}$

In addition to online learning during the COVID-19 outbreak, schoolage children may need a lot of free time to be accompanied, more so for subjects that require high concentration, as shown by the results of this study, that Mathematics, English, Natural Sciences are subjects that require high concentration. Regarding the most difficult of all subjects, 
this has been identified by other studies, ${ }^{22}$ but it is not a burden for parents, even though it is at risk for the child's academic achievement. The results of the research also report that children turn their attention to other activities when facing difficulties, such as playing online games in which this research strongly supports these findings. This is very worrying when the child goes into a state of addiction. Moreover, the age of children is the age of searching for social identity. ${ }^{23}$ Concerning the importance of accompanying children when learning online, a study shows that due to online learning during the COVID-19 outbreak, some parents, including mothers, are willing to leave their jobs, ${ }^{24}$ so it has a negative impact on their finance, which can affect their resilience, but not for parents of children with autism. ${ }^{25}$

Other findings also showed that the gender of the children was another predictor of parental resilience so that parents with girls who took online learning were more resilient than parents who had boys. Previous research has also found that parents are stressed by online learning, especially parents with boys, ${ }^{4}$ thus it will affect their toughness so that parents pay more attention to boys than girls. ${ }^{26}$

\subsection{Implication for nursing practice}

Learning in the classroom can not be expected because of the COVID19 pandemic in Indonesia to avoid the spread and occurrence of crossinfection between students and other officers. ${ }^{27}$ It is very burdensome for their parents when learning in the class is diverted to learning at home through online learning, and the main reaction of parents due to online learning at home for their children is related to psychological disorders such as depression, anxiety and stress. ${ }^{2}$ However, there is a moral responsibility of parents towards their children who do online learning to be actively involved in online learning, ${ }^{28}$ although there are still many other tasks to be completed. Besides, parents act as liaisons with their classroom teachers, as shown in the analysis and identification in other research, that parents can still be involved in critical reflection on their child's subject in which they provide assistance in overcoming their child's difficulties while doing online learning. ${ }^{29}$ Thus, assisting their children in undergoing online learning to support the sustainability of classroom teaching programs for parents is very important to support their children's academic achievements. ${ }^{30}$ This is as important as the role of the teacher towards his students due to the many obstacles faced by parents when accompanying their children in learning online due to the COVID-19 pandemic such as finance, stress due to changes in online learning paradigm, and others.

\section{Conclusion}

This research is focused on investigating factors that can predict parental resilience regarding online learning during the COVID-19 outbreak. The main conclusion of this study is that the resilience of male parents is better than that of female parents. And parents who have daughters are tougher than parents who have sons. Also, to anticipate the potential threat of COVID-19 and the threat of future health pandemics, strengthening the socio-economic and creative learning settings are very important things to pay attention to, besides not ignoring the real threat of the impact of the COVID-19 pandemic on health globally, so that everything does not become a threat in the future. Health care providers need to identify parents who are at risk and provide them with psychological support, education, and counseling regarding online learning mentoring strategies for their children.

\section{Source of funding}

The authors received no financial support for the research, authorship, and/or publication of this article.

\section{Declaration of competing interest}

All authors critically revised the article, gave final approval for the submission of the article, and agreed to be responsible for all aspects of the work in ensuring that questions related to the accuracy or integrity of each part of the work were properly researched and resolved. And there are no conflicts of interest.

\section{Acknowledgment}

The authors would like to thank the parents of the children conducting online learning as the participants in this study. The researchers also expressed gratitude to the administrators at the institution who have helped and supported this research.

\section{References}

1 Jin YH, et al. Perceived infection transmission routes, infection control practices, psychosocial changes, and management of COVID-19 infected healthcare workers in a tertiary acute care hospital in Wuhan: a cross-sectional survey. Mil. Med. Res. 2020; 7:1-13.

2 Brown SM, Doom JR, Lechuga-Peña S, Watamura SE, Koppels T. Stress and parenting during the global COVID-19 pandemic. Child Abus. Negl. 2020 https://doi.org/ 10.1016/j.chiabu.2020.104699.

3 Lee J. Mental health effects of school closures during COVID-19. Lancet Child Adolesc. Heal. 2020;4:421.

4 Susilowati E, Azzasyofia M. The parents stress level in facing children study from home in the early of covid-19 pandemic in Indonesia. Int J Sci Soc. 2020;2:1-12.

5 Nasir A, Yusuf A, Listiawan MY, Harianto S, Huda N. Adaptive strategy of women. In: $s$ Leprosy in Indonesia Psychic Experience of Women with Leprosy in Living a Community Life. vol. 11. 2020:306-312.

6 Serafini G, et al. The psychological impact of COVID-19 on the mental health in the general population. Qjm. 2020;113:229-235.

7 Whiting M, Nash AS, Kendall S, Roberts SA. Enhancing resilience and self-efficacy in the parents of children with disabilities and complex health needs. Prim Health Care Res Dev. 2019;20:e33.

8 Smith GD, Ng F, Ho Cheung Li W. COVID-19: emerging compassion, courage and resilience in the face of misinformation and adversity. J Clin Nurs. 2020;29: 1425-1428.

9 Zautra A, Murray K. Resilience: A New Definition of Health for People and Communities. 2014.

$10 \mathrm{Cal} \mathrm{SF}$, et al. Resilience in chronic diseases : a systematic review Resilience in chronic diseases : a systematic review. Cogent Psychol. 2015;39.

11 Connor KM, Davidson JRT. Development of a new resilience scale: the connorDavidson resilience scale (CD-RISC). Depress Anxiety. 2003;18:76-82.

12 Lai J, Poletiek FH. The impact of adjacent-dependencies and staged-input on the learnability of center-embedded hierarchical structures. Cognition. 2011;118: 265-273.

13 Habibpour Z, Mahmoudi H, Nir MS, Areshtanab HN. Resilience and its predictors among the parents of children with cancer: a descriptive-correlational study. Indian $J$ Palliat Care. 2019;25:79-83.

14 Mital AK, Sabnis SG, Kulkarni VV. Caregiver burden in medical versus psychiatric patients: a cross-sectional comparative study. Indian J Psychol Med. 2017;39: $777-784$.

15 Rajan AM, Romate J, Srikrishna G. Resilience of parents having children with intellectual disability: influence of parent and child related demographic factors. Indian J. Heal. Wellbeing. 2016;7:707-710.

16 Van Riper M. Families of children with Down syndrome: responding to 'A change in plans' with resilience. J Pediatr Nurs. 2007;22:116-128.

17 Ilias K, Cornish K, Kummar AS, Park MSA, Golden KJ. Parenting stress and resilience in parents of children with autism spectrum disorder (ASD) in Southeast Asia: a systematic review. Front Psychol. 2018;9.

18 Papageorgiou Y, Petousi V. Gender resilience in times of economic crisis: findings from Greece. Partecip. e Conflitto. 2018;11:145-174.

19 Reyes MF, Satorres E, Meléndez JC. Resilience and socioeconomic status as predictors of life satisfaction and psychological well-being in Colombian older adults. J Appl Gerontol. 2020;39:269-276.

20 Ravera F, Iniesta-Arandia I, Martín-López B, Pascual U, Bose P. Gender perspectives in resilience, vulnerability and adaptation to global environmental change. Ambio. 2016;45:235-247.

21 Kavaliotis P. Resilience of parents with a child with autism spectrum disorders and factors for its potential enhancement: family income and educational level. J Educ Dev Psychol. 2017;7:188.

22 Lodge JM, Kennedy G, Lockyer L, Arguel A, Pachman M. Understanding difficulties and resulting confusion in learning: an integrative review. Front. Educ. 2018;3:1-10.

23 Duman H, Ozkara BY. The impact of social identity on online game addiction: the mediating role of the fear of missing out (FoMO) and the moderating role of the need to belong. Curr Psychol. 2019. https://doi.org/10.1007/s12144-019-00392-w.

24 Shammi M, Bodrud-Doza M, Towfiqul Islam ARM, Rahman MM. COVID-19 pandemic, socioeconomic crisis and human stress in resource-limited settings: a case from Bangladesh. Heliyon. 2020;6, e04063. 
25 Sinha D, Verma N, Hershe D. A comparative study of parenting styles, parental stress and resilience among parents of children having autism spectrum disorder, parents of children having specific learning disorder and parents of children not Diagnosed with any psychiatric disorder. Ann Int Med Dent Res. 2016;2.

26 Choi EJ, Hwang J. Child gender and parental inputs: No more son preference in Korea? Am Econ Rev. 2015;105:638-643.

27 Hamid R, Sentryo I, Hasan Universitas Halu Oleo Jalan HEA Mokodompit Kampus Hijau Bumi Tridharma S. Online learning and its problems in the Covid-19 emergency period. J. Prima Edukasia. 2020;8:86-95.
28 Stevens M, Borup J. Parental engagement in online learning environments: a review of the literature. Adv Res Teach. 2015;25:99-119.

29 Abidah A, Hidaayatullaah HN, Simamora RM, Fehabutar D, Mutakinati L. The impact of covid-19 to Indonesian education and its relation to the philosophy of "merdeka belajar". Stud. Philos. Sci. Educ. 2020;1:38-49.

30 Kelty NE, Wakabayashi T. Family Engagement in Schools: Parent, Educator, and Community Perspectives. vol. 10. SAGE Open; 2020. 